\title{
GMINA WOBEC OBSZARÓW NATURA 2000
}

\section{NATURA 2000 SITES AND MUNICIPALITY}

\author{
http://dx.doi.org/10.12775/PPOS.2015.038
}

\section{STRESZCZENIE}

Analiza pozycji prawnej gmin względem obszarów Natura 2000, będąca przedmiotem niniejszego artykułu, sprowadza się do trzech zagadnień: tworzenia tych obszarów, planowania miejscowego na tych obszarach lub w ich bezpośrednim otoczeniu oraz gospodarowania nimi. O ile przy tworzeniu obszarów Natura 2000 rola gminy jest ważna, ale niewiodąca, o tyle ciężar zarządzania obszarami Natura 2000 spoczywa na tej jednostce samorządu terytorialnego. Planowanie miejscowe i gospodarowanie są względem siebie komplementarne, można je określić mianem zarządzania obszarami Natura 2000. Związek pomiędzy tymi czynnościami wyraża się także i w tym, że etap podjęcia aktywności gospodarczej na danym terenie zawsze musi zostać poprzedzony spełnieniem przesłanek, wynikających z ustawy o planowaniu i zagospodarowaniu przestrzennym. Oddziaływanie

Doktor nauk prawnych, Katedra Postępowania Administracyjnego i Procedur Środowiskowych Wydziału Prawa i Administracji Uniwersytetu Opolskiego. 
gminy na ochronę i zagospodarowanie obszarów Natura 2000 odbywa się za pomocą narzędzi prawnych planowania oraz zagospodarowania przestrzennego. Gmina, ustalając przeznaczenie i zasady zagospodarowania danego terenu, nie może pominąć występowania obszarowych form ochrony przyrody, w tym obszarów Natura 2000. Ważnym instrumentem, za pomocą którego gmina kreuje otoczenie obszaru Natura 2000 jest przeprowadzenie strategicznej oceny oddziaływania na środowisko dokumentów planistycznych. Występowanie obszarów Natura 2000 może być i często jest katalizatorem rozwoju gmin, a także stanowi instrument ich zrównoważonego rozwoju.

\section{Słowa kluczowe}

Obszary Natura 2000; planowanie miejscowe; gmina.

\section{ABSTRACT}

The analysis of the legal position of municipalities in relation to Natura 2000, which is the subject of this article, comes down to three issues: the creation of these areas, local planning in these areas or in their immediate surrounding and their management. While the role of municipalities is important, but not leading, in the creation of Natura 2000 sites, the responsibility of the management of those sites lies with this local government unit. Local planning and management are mutually complementary and can be described as the management of Natura 2000 sites. The relationship between these activities is expressed also in the fact that the stage of undertaking an economic activity in a given area must always be preceded by the fulfilment of the conditions resulting from the Act on Spatial Planning and Development. The impact of the municipality on the protection and management of Natura 2000 sites is created with the use of legal planning and spatial management tools. While determining the purpose and principles of development of an area, a municipality cannot ignore the presence of area forms of nature protection, including Natura 2000 sites. An important instrument through which a municipality creates a Natura 2000 site is to carry out a strategic environmental impact assessment of planning documents. The presence of Natura 2000 sites can be and often is development accelerator for municipalities and an instrument of their sustainable development.

\section{Keywords}

Natura 2000; local planning; municipality. 


\section{WPROWADZENIE}

Członkostwo Polski w Unii Europejskiej wiąże się z przejęciem i realizowaniem przez organy administracji licznych obowiązków publicznoprawnych. Europejski porządek prawny, nakładając na krajowe organy administracji publicznej nowe zadania, czyni zeń organy częściowo unijne ${ }^{1}$. Pomimo trwającego już ponad dekadę członkostwa w strukturach europejskich, stosowanie prawa europejskiego stanowi nadal dla organów administracji ogromne wyzwanie ${ }^{2}$. Organy administracji publicznej stale stykają się z problematyką stosowania prawa unijnego i potrzebą interpretacji orzecznictwa Trybunału Sprawiedliwości Unii Europejskiej, przede wszystkim w tych sprawach, w których przedmiotowy zakres działania danego organu tego wymaga.

Zasadniczy ciężar prac związanych ze stosowaniem prawa unijnego spoczywa na organach krajowych ${ }^{3}$. Obowiązki stąd wynikające podzielone są pomiędzy władze centralne, regionalne i lokalne ${ }^{4}$, przy czym w wielu przypadkach to właśnie organy znajdujące się na najniższych szczeblach administracji publicz-

1 Por. S. Dudzik, Konstytucyjna pozycja samorzadu terytorialnego a perspektywy integracji europejskiej, w: Konstytucja Rzeczypospolitej Polskiej z 1997 roku a członkostwo Polski w Unii Europejskiej, red. C. Mik, Toruń 1999, s. 243 i nast.; T. Rabska, Administracja publiczna $w$ świetle integracji z Unia Europejska, „Samorząd Terytorialny” 2003, nr 3, s. 4.

2 Por. A. Nowak-Far, Stosowanie acquis communautaire przez administracje publiczne państw członkowskich Unii Europejskiej - zagadnienia prawne i organizacyjne, „Służba Cywilna” 2002, nr 4, s. 37 i nast.; A. Gajda, Organy regionalne i lokalne a prawo wspólnotowe, w: Efektywność prawa wspólnotowego w Polsce. Wybrane problemy, red. J. Barcz, „Studia z dziedziny prawa Unii Europejskiej" 2005, nr 3, s. 109; E. D. Sage, Stosowanie prawa i polityk Unii Europejskiej przez władze lokalne, Warszawa 2000, s. 36.

3 Por. C. Mik, Polskie organy państwowe wobec perspektywy przystąienia $R P$ do Unii Europejskiej, w: Polska w Unii Europejskiej. Perspektywy, warunki, szanse i zagrożenia, red. C. Mik, TNOiK Toruń 1997, s. 243.

4 A. Nowak-Far, op. cit., s. 31 i nast. 
nej (organy samorządu terytorialnego) ponoszą największe ciężary z tym związane ${ }^{5}$.

Jednym z obszarów prawa, które w największym stopniu zostało zeuropeizowane jest prawo ochrony środowiska. Prawo to na poziomie unijnym, pomimo rozwoju regulacji horyzontalnych, ma charakter sektorowy, tzn. dotyczy poszczególnych elementów środowiska lub rodzajów uciążliwości. Najważniejszym wyzwaniem podjętym na płaszczyźnie europejskiej jest ochrona różnorodności biologicznej ${ }^{6}$, zaś obszary Natura 2000 są jej określonym prawnie przejawem. Obejmują bowiem swoim zasięgiem tereny szczególnie cenne przyrodniczo, ważne z punktu widzenia zachowania zagrożonych lub bardzo rzadkich gatunków roślin i zwierząt oraz istotnych dla zachowania bioróżnorodności Europy siedlisk przyrodniczych. Za wyznaczaniem obszarów Natura 2000 stoją przede wszystkim względy przyrodnicze, jednak obszary te mogą być i często są katalizatorem rozwoju gmin, stanowiąc instrument ich zrównoważonego rozwoju. Unia Europejska nie przyznaje jednak bezwzględnego pierwszeństwa ochronie środowiska przed względami społecznymi czy gospodarczymi ${ }^{7}$.

Utworzenie obszarów Natura 2000 jest konsekwencją implementacji przepisów prawa europejskiego: Dyrektywy Rady nr 92/43/EWG z dnia 21 maja 1992 roku w sprawie ochrony

5 Zob. M. Zieliński, Wpływ członkostwa Polski w Unii Europejskiej na samorzad terytorialny, w: Przystapienie Polski do Unii Europejskiej. Traktat Akcesyjny $i$ jego skutki, red. S. Biernat, S. Dudzik, M. Niedźwiedź, Kraków 2003, s. 263.

6 Jak zauważa J. Ciechanowicz, na całym świecie obserwuje się gwałtowny spadek bioróżnorodności, co jest następstwem nadmiernej eksploatacji zasobów przyrody ożywionej i nieożywionej, zanieczyszczeń środowiska, niewłaściwej introdukcji obcych gatunków roślin i zwierząt, a przede wszystkim - niszczeniem siedlisk. Zob. J. Ciechanowicz, Międzynarodowe prawo ochrony środowiska, Warszawa 1999, s. 90.

7 Por. L. Tomiałojć, Sustainable Development and Nature Conservation the Necessity for Compromise instead of Confrontation, "Economic and Environmental Studies" 2006, nr 8, s. 30.; cyt za: A. Haładyj, Udział społeczeństwa $w$ strategicznej ocenie oddziaływania na środowisko jako instytucja prawa ochrony środowiska, Lublin 2015, s. 166. 
siedlisk przyrodniczych oraz dzikiej fauny i flory ${ }^{8}$ - zwanej dyrektywą siedliskową lub habitatową oraz Dyrektywy Parlamentu Europejskiego i Rady nr 2009/147/WE z dnia 30 listopada 2009 r. w sprawie ochrony dzikiego ptactwa ${ }^{9}$ zwanej dyrektywą ptasią. Wymienione dyrektywy zakładają stworzenie kompleksowego systemu ochrony zasobów bioróżnorodności, poprzez spójną w skali całej Europy sieć Natura 2000. Sieć tworzą dwa odrębne podsystemy obszarów chronionych: OSO - obszary specjalnej ochrony ptaków (tzw. obszary „ptasie”), które mają na celu ochronę ptaków i ich siedlisk, wyznaczane są indywidualnie zarówno w części kontynentalnej oraz na obszarach morskich, SOO - specjalne obszary ochrony siedlisk (tzw. obszary "siedliskowe”), w których przedmiotem ochrony są wymagające działań ochronnych siedliska przyrodnicze, mające znaczenie dla zachowania wartości przyrodniczych Unii Europejskiej oraz wybrane cenne gatunki roślin i zwierząt (poza ptakami). Natura 2000 to nie tylko obszary najcenniejsze w Unii, ale również tereny, które stanowią kanały łącznikowe pomiędzy tymi najcenniejszymi obszarami. (korytarze ekologiczne umożliwiające migrację organizmów między siedliskami ${ }^{10}$ ). Stosunek obszarów Natura 2000 względem innych form ochrony przyrody, określony w art. 25 ust. 2 ustawy o ochronie przyrody ${ }^{11}$, czyni z tej formy obszar, na którym obowiązuje tzw. podwójny reżim publicznoprawny ${ }^{12}$ charakterystyczny dla tej stosunkowo nowej formy oraz dla formy zastanej, np. parku narodowego lub rezerwatu przyrody. Sieć obejmuje swoim zasięgiem zarówno

8 Dz. Urz. UE L 206, s. 7 z późn. zm.

9 Dz. Urz. UE z 2010 r. L 20, s. 7 z późn. zm.

10 Funkcję korytarzy pełnią lasy, tereny porośnięte krzewami i trawami, tereny wodno-błotne, w szczególności tereny dolin rzecznych. Poza możliwościami przemieszczania się zapewniają gatunkom warunki do zdobycia pożywienia, ustanowienia terytorium, znalezienia partnera do rozrodu oraz umożliwiają ucieczkę przed niebezpieczeństwem (np. przed drapieżnikami, pożarem itd.).

11 Ustawa z dnia 16 kwietnia 2004 r. o ochronie przyrody, t.j. Dz.U. z 2015 r., poz. 1651 ze zm. (dalej: u.o.p.).

12 Por. A. Kaźmierska-Patrzyczna, Istota prawna obszarów Natura 2000 uwagi ogólne, w: Problemy wdrażania systemu Natura 2000 w Polsce, red. A. Kaźmierska-Patrzyczna, M. A. Król, Szczecin-Łódź-Poznań 2013, s. 47. 
krajowe obszary prawnie chronione, jak i tereny, na których nie występowała dotąd żadna inna forma ochrony przyrody. W konsekwencji obecnie w Polsce Natura 2000 zajmuje prawie $20 \%$ powierzchni lądowej ${ }^{13}$. Natura 2000 rozłożona jest przy tym nierównomiernie ${ }^{14}$, czego konsekwencją jest, że nie każda gmina jest żywo zainteresowana problematyką obszarów Natura 2000. Są gminy w całości pokryte obszarami Natura 2000 (np. Jedwabno). Są też i takie, na których ta forma przyrodnicza nie występuje. Największa ilość gmin posiada obszary Natura $2000 \mathrm{w}$ wielkości 1-10\% swojej powierzchni ${ }^{15}$.

Analiza pozycji prawnej gmin względem obszarów Natura 2000 sprowadza się do trzech zagadnień: tworzenia tych obszarów, planowania miejscowego na tych obszarach lub w ich bezpośrednim otoczeniu oraz gospodarowania nimi. Dwie ostatnie czynności: planowanie i gospodarowanie są względem siebie komplementarne, można je określić mianem zarządzania obszarami Natura 2000. O ile przy tworzeniu rola gminy jest istotna, ale niewiodąca, o tyle ciężar zarządzania obszarami Natura 2000 spoczywa na tej jednostce samorządu terytorialnego. Poza zakresem analiz pozostawiono problematykę ewentualnych rekompensat za ograniczenia związane z korzystaniem z nieruchomości lub obniżeniem dochodów z działalności gospodarczej, rolnej, leśnej, rybackiej i łowieckiej, prowadzonej na obszarach Natura 2000. Zagadnienie to - zdaniem autorki pretenduje do odrębnych rozważań.

13 W jej skład wchodzi 849 obszarów siedliskowych oraz 145 obszarów ptasich.

14 Największa część polskich obszarów Natura 2000 jest położona w granicach województwa zachodniopomorskiego (około 16\%), warmińsko-mazurskiego i podlaskiego (po około 11\%). Najmniej obszarów Natura 2000 znajduje się w województwie opolskim (mniej niż 1\%) oraz w województwach łódzkim, kujawsko-pomorskim i świętokrzyskim (w każdym z województw po około 1\% łącznej powierzchni obszarów Natura 2000 w Polsce). Zob. Ekspertyza przekrojowa dotyczaca ekonomicznych uwarunkowań gospodarowania na Obszarach Natura 2000, Białystok 2012, źródło: http://www.natura2000. efort.pl/pliki/ekspertyza_ekonomiczna1.pdf, s. 16 [dostęp: 6 października 2015 r.].

15 Ibidem, s. 20. 


\section{TWORZENIE OBSZARÓW NATURA 2000}

W tworzenie oraz funkcjonowanie obszarów Natura 2000 w Polsce włączone są struktury administracji na każdym poziomie zarządzania państwem, mianowicie: organy naczelne (Minister Środowiska), organy centralne (Generalny Dyrektor Ochrony Środowiska, Główny Inspektor Ochrony Środowiska) oraz organy terenowe zarówno rządowe (Regionalny Dyrektor Ochrony Środowiska), jak i organy samorządu terytorialnego. Jeśli chodzi o tworzenie obszarów Natura 2000, to - zgodnie z art. 27, ust. 2 u.o.p. - projekt listy obszarów Natura 2000 opracowany przez Generalnego Dyrektora Ochrony Środowiska, podług przepisów prawa Unii Europejskiej, wymaga zasięgnięcia opinii właściwych miejscowo rad gmin. Niezłożenie opinii w terminie 30 dni od dnia otrzymania projektu uznaje się za brak uwag. Opiniowanie jest formą wypowiedzenia się danego podmiotu w sprawie, która ma charakter niewiążący dla organu rozstrzygającego ${ }^{16}$. Obowiązkiem organu głównego jest przeanalizowanie nadesłanych opinii i podjęcie decyzji co do zakresu, w jakim dana opinia zostanie uwzględniona.

Początkowo tworzenie obszarów Natura 2000 odbywało się z niemałymi oporami ze strony samorządów. Wiązało się to z brakiem rzetelnej informacji na temat, czym jest Natura 2000 i jakie skutki dla gmin pociąga za sobą wyznaczenie tego obszaru. W obszarach Natura 2000 upatrywano bowiem barierę w inwestowaniu i rozwoju gminy poprzez wydłużenie postępowania administracyjnego oraz liczne utrudnienia i opóźnienia w planowaniu, a także realizacji inwestycji lokalnych. Część przedstawicieli samorządu dostrzegała pozytywne aspekty funkcjonowania obszarów Natura 2000 na terenie gminy, np. poprawę stanu środowiska naturalnego, rozwój turystyki i rol-

16 Inaczej rzecz się przedstawia w przypadku uzgodnienia. W doktrynie prawa i postępowania administracyjnego uznaje się, że treść stanowiska wyrażona w formie uzgodnienia wiąże organ prowadzący postępowanie główne. Zob. J. Borkowski, Kodeks Postępowania Administracyjnego - Komentarz, Warszawa 1996, s. 468. 
nictwa ekologicznego, zwiększenie świadomości ekologicznej mieszkańców oraz ułatwiony dostęp do zewnętrznych źródeł finansowania. Korzyści te nie zdominowały jednak obaw samorządów i - przynajmniej w początkowym okresie - tworzeniu obszarów Natura 2000 towarzyszyło przekonanie, że ich utworzenie spowoduje spowolnienie procesów inwestycyjnych. Brak działań informacyjnych i popularyzujących znaczenie obszarów Natura 2000 i ich roli dla podniesienia jakości środowiska, a tym samym jakości życia ludzi, należy odnotować jako istotny problem na etapie tworzenia obszarów Natura 2000. Z czasem jednak zwiększył się poziom wiedzy o obszarach Natura 2000, a przedstawiciele samorządów dostrzegli w nich dotąd niezauważony potencjał.

\section{PLANOWANIE MIEJSCOWE NA OBSZARACH NATURA 2000 LUB W ICH BEZPOŚREDNIM OTOCZENIU}

Drugim punktem, w którym uwidacznia się rola gminy jest zarządzanie obszarami Natura 2000, na które składają się dwie czynności: planowanie i gospodarowanie. Czynności te są ze sobą immanentnie związane, ponieważ etap podjęcia aktywności gospodarczej na danym terenie zawsze musi zostać poprzedzony spełnieniem przesłanek wynikających z ustawy o planowaniu i zagospodarowaniu przestrzennym ${ }^{17}$. Planowanie przestrzenne, jak podkreśla J. Stelmasiak, jest etapem wstępnym, po którym następuje zagospodarowanie przestrzeni, a sama przestrzeń jest swoistym tłem dla zjawisk, które niosą ze sobą z jednej strony zagrożenia dla środowiska, z drugiej strony są $\mathrm{w}$ niej realizowane konieczne działania ochronne wobec środowiska ${ }^{18}$. Odnosząc się do tego poglądu, można stwierdzić, że występowanie obszarów Natura 2000 jest związane z przy-

17 Ustawa z dnia 27 marca 2003 r. o planowaniu i zagospodarowaniu przestrzennym, tj. Dz.U. z 2015, poz. 199, 443, 774, 1265.

18 J. Stelmasiak, Miejscowy plan zagospodarowania przestrzennego jako prawny środek ochrony środowiska, Lublin 1994; idem, Interes indywidualny 
sporzeniem przestrzeni wartości dodanej i na obszarach tych konieczne są działania ochronne, przy czym działania te nie muszą oznaczać rezygnacji z korzystania z tego zasobu w celach gospodarczych.

Oddziaływanie gminy na ochronę i zagospodarowanie obszarów Natura 2000 odbywa się za pomocą narzędzi prawnych planowania oraz zagospodarowania przestrzennego. Centralne miejsce pośród tych narzędzi zajmuje miejscowy plan zagospodarowania przestrzennego (zwany dalej m.p.z.p.), który jest jednym z kluczowych środków prawnych służących ochronie środowiska ${ }^{19}$. Jako podstawowe źródło informacji o przeznaczeniu terenów na określone cele stanowi o wymaganiach techniczno-przyrodniczych, które winny być spełnione przy lokalizacji inwestycji ${ }^{20}$. Bolączką planowania miejscowego jest, że m.p.z.p. uchwala się dla coraz mniejszych obszarów, co określa się mianem fragmentacji planowania. Miejscowe plany zagospodarowania przestrzennego mają także wiele słabości merytorycznych, spośród których najpoważniejsze to: niewłaściwa i nieprecyzyjna diagnoza stanu istniejącego oraz brak odniesień planistycznych do stanu aktualnego (planowanie $\mathrm{z}$ pominięciem dotychczasowych, już istniejących inwestycji, planowanie bez właściwej diagnozy sytuacji przyrodniczej w gminie). Ów brak odniesień planów do stanu istniejącego jest najpoważniejszym ich mankamentem, co w konsekwencji może prowadzić do przestrzennych patologii ${ }^{21}$. Na obszarach, na których znajdują się obszary Natura 2000 zjawisko to może skutkować

a interes publiczny $w$ ochronie środowiska $w$ obszarze specjalnym o charakterze ekologicznym, Rzeszów 2013, s. 11.

19 Zob. na ten temat przede wszystkim J. Stelmasiak, op. cit., s. 5; K. Nowacki, Zadania, kompetencje i formy działania organów administracji publicznej $w$ dziedzinie ochrony środowiska $i$ zagospodarowania przestrzennego (wybrane problemy), w: Ustrój administracji publicznej, red. E. J. Nowacka, Warszawa 2000, s. 91-130 (wskazuje na liczne związki pomiędzy prawem ochrony środowiska a prawem zagospodarowania przestrzennego).

20 Zob. R. Paczuski, Prawo ochrony środowiska Unii Europejskiej w zarysie, Toruń 1999, s. 202.

21 Zob. M. Jać, P. Jać, Planowanie przestrzenne - o potrzebie i kierunkach zmian, w: Kierunki reformy prawa planowania $i$ zagospodarowania przestrzennego, red. I. Zachariasz, Warszawa 2012, s. 301-302. 
niewłaściwym wykorzystaniem potencjału obszaru Natura 2000 i osłabieniem w ten sposób możliwości rozwojowych gminy.

Gmina ustalając przeznaczenie i zasady zagospodarowania danego terenu nie może pominąć występowania obszarowych form ochrony przyrody, w tym obszarów Natura 2000. Konsekwencją pominięcia wymagań środowiskowych w planowaniu przestrzennym jest nieważność studium uwarunkowań i kierunków zagospodarowania przestrzennego gminy lub miejscowego planu zagospodarowania przestrzennego stwierdzana przed wojewodę w trybie nadzoru. Ważną wytyczną dla planowania miejscowego jest też, że w miejscowym planie zagospodarowania przestrzennego, $\mathrm{a}-\mathrm{w}$ razie jego braku $-\mathrm{w}$ decyzji o warunkach zabudowy uwzględnia się ograniczenia, wynikające z ustanowienia m.in. obszaru Natura 2000 (art. 73 ust. 1 pkt 1 ustawy Prawo ochrony środowiska) ${ }^{22}$.

Kolejnym istotnym zagadnieniem rzutującym na sytuację prawną gminy, na której występują obszary Natura 2000 jest kompatybilność planowania ogólnego i planowania specjalistycznego, co - w odniesieniu do obszaru Natura 2000 - oznacza konieczność uwzględniania wymagań planu ochrony obszaru Natura 2000 w planowaniu miejscowym. Zgodnie z art. 29, ust. 8 pkt. 4 u.o.p. plan ochrony dla obszaru Natura 2000 zawiera wskazania do zmian $\mathrm{w}$ istniejących studiach uwarunkowań i kierunków zagospodarowania przestrzennego gmin oraz miejscowych planach zagospodarowania przestrzennego, dotyczące eliminacji lub ograniczenia zagrożeń wewnętrznych lub zewnętrznych, jeżeli są niezbędne dla utrzymania lub odtworzenia właściwego stanu ochrony siedlisk przyrodniczych oraz gatunków roślin i zwierząt, dla których wyznaczono obszar Natura 2000. Regulacja ta stanowi instrument kształtowania treści ustaleń gminnych aktów planistycznych w sposób uwzględniający wymogi ochrony przyrody. Umożliwia przy tym zawarcie w m.p.z.p. takich ustaleń dotyczących sposobu wykonywania prawa własności, aby możliwa była realizacja celów ochrony

22 Ustawa Prawo ochrony środowiska (dalej: p.o.ś) z dnia 27 kwietnia 2001 roku, t.j. Dz.U. z 2013 r., poz. 1232, z późn. zm. 
obszarów Natura $2000^{23}$. Innym narzędziem prawnym, którego celem jest wyeliminowanie sprzeczności pomiędzy aktami z zakresu planowania przestrzennego a postanowieniami planów ochrony Natura 2000 są uzgodnienia z regionalnym dyrektorem ochrony środowiska $\mathrm{w}$ zakresie postanowień tych planów, których realizacja może znacząco negatywnie oddziaływać na obszar Natura $2000^{24}$.

Zapewnienie ochrony walorów przyrodniczych powinno nastąpić - w myśl art. 72 ustawy Prawo ochrony środowiska ${ }^{25}$ - poprzez określenie wymagań ochronnych w aktach planistycznych. Wymagania te określa się na podstawie opracowań ekofizjograficznych, stosownie do rodzaju sporządzanego dokumentu, cech poszczególnych elementów przyrodniczych i ich wzajemnych powiązań (art. 72 ust.4 ustawy u.p.o.ś.) ${ }^{26}$. Opracowanie pełni funkcję informacyjną w pracach nad aktem planistycznym i nie może zastępować tego aktu ani pełnić funkcji

23 D. Trzcińska, Natura 2000 a ograniczenie korzystania z nieruchomości, w: Wybrane problemy prawa ochrony środowiska, red. B. Rakoczy, M. Pchałek, Warszawa 2010, s. 149. Zgodzić się wypada z Autorką, że regulacje prawne dotyczące ochrony przyrody pozostają w ścisłym związku z unormowaniami $\mathrm{z}$ dziedziny planowania i zagospodarowania przestrzennego.

24 Warto w tym miejscu podkreślić, że uzgodnienia planów, strategii i programów należy uznać za czynności faktyczne, o treści materialnej, należące do środków koordynacji. Zob. M. A. Waligórski, Koordynacja $w$ administracji publicznej, w: Ewolucja prawnych form administracji publicznej. Księga jubileuszowa z okazji 60 rocznicy urodzin profesora Ernesta Knosali, red. L. Zacharko, AS. Matan, G. Łaszczyca, Warszawa 2008, s. 318.

25 Ustawa z dnia 27 kwietnia 2001 r. Prawo ochrony środowiska, t.j. Dz.U. z 2013 r., poz. 1232, z późn. zm. (dalej: u.p.o.ś.).

26 Ustawa przy tym wyjaśnia, że przez opracowanie ekofizjograficzne rozumie się dokumentację sporządzaną na potrzeby studium uwarunkowań i kierunków zagospodarowania przestrzennego gminy, miejscowego planu zagospodarowania przestrzennego oraz planu zagospodarowania przestrzennego województwa, charakteryzującą poszczególne elementy przyrodnicze na obszarze objętym studium lub planem i ich wzajemne powiązania (art. 72, ust. 5 u.p.o.ś.). Zakres i sposób wykonania opracowań ekofizjograficznych określony został szczegółowo w rozporządzeniu Ministra Środowiska z dnia 9 września 2002 r. w sprawie opracowań ekofizjograficznych. Dz.U. Nr. 155, poz. 1298. 
rozstrzygającej ${ }^{27}$. Stanowi ono podstawę do kreowania przestrzeni z poszanowaniem środowiska przyrodniczego i krajobrazu, a - jeśli zachodzi potrzeba dokonania zmian w przeznaczeniu terenów - należy dokonać tych zmian przez skorygowanie zasad ochrony w treści dokumentów planistycznych. Dostarczone w opracowaniu informacje o środowisku przyrodniczym mają wpływ nie tylko na przyszłe rozwiązania planistyczne, ale także na konstrukcję prognozy oddziaływania na środowisko, a więc opracowania mającego istotne znaczenie dla środowiska, przyrody i krajobrazu, będącego efektem końcowym przeprowadzenia strategicznej oceny oddziaływania na środowisko. Opracowanie ma charakter służebny względem dokumentu planistycznego, ale nie może być pominięte. Należy wskazać w nim tereny istniejących i projektowanych obszarów Natura 2000; tereny, w obrębie których inwestycje wymagają oceny pod kątem oddziaływania na obszary Natura 2000; tereny, które mają znaczenie dla właściwego funkcjonowania obszarów Natura 2000 poprzez zapewnienie im łączności z innymi cennymi terenami przyrodniczymi (korytarze ekologiczne) względnie te, na których realizacja nowych inwestycji może stwarzać potencjalne zagrożenia dla funkcjonowania i przedmiotu ochrony obszarów Natura 2000.

\section{STRATEGICZNA OCENA ODDZIAŁYWANIA PLANU MIEJSCOWEGO LUB INNYCH DOKUMENTÓW PLANISTYCZNYCH NA OBSZAR NATURA 2000}

Kolejnym wymogiem prawnym, związanym z aktywnością gmin wobec obszarów Natura 2000, jest obowiązek przeprowadzenia strategicznej oceny oddziaływania planu miejscowego lub innych dokumentów planistycznych na obszar Natura 2000, wy-

27 Wyrok WSA z dnia 31 maja 2007 r., II SA/Bk 77/07, „Wspólnota” 2008, nr 2, s. 31. 
nikający z ustawy z dnia 3 października 2008 roku o udostępnianiu informacji o środowisku i jego ochronie, udziale społeczeństwa w ochronie środowiska oraz o ocenach oddziaływania na środowisko ${ }^{28}$, zwanej oceną habitatową. Ten szczególny rodzaj oceny środowiskowej służy badaniu, czy i w jaki sposób dany dokument oddziałuje na obszar Natura 2000. Celem przeprowadzenia oceny oddziaływania na środowisko każdego projektu dokumentu (czyli strategicznej oceny oddziaływania na środowisko - SOOŚ) jest przede wszystkim określenie wpływu projektowanego dokumentu na środowisko. Oznacza to, że organ opracowujący projekt dokumentu musi wziąć pod uwagę ustalenia zawarte w prognozie oddziaływania na środowisko, a także opinie organów oraz rozpatrzyć uwagi i wnioski zgłoszone z udziałem społeczeństwa ${ }^{29}$. W przypadku stwierdzenia $\mathrm{w}$ pierwszych etapach oceny (rozpoznanie i ocena właściwa), iż oddziaływanie na cele obszaru Natura 2000 jest znacząco negatywne oraz ingeruje w jego integralność, nie można zrealizować dokumentu, chyba że w kolejnych etapach oceny stwierdzi się, iż łącznie występują przesłanki szczególne: brak rozwiązań alternatywnych, obecność koniecznych wymogów nadrzędnego interesu publicznego, możliwość wykonania kompensacji przyrodniczej zapewniającej lub przywracającej spójność sieci Natura 2000.

Środowiskową przesłanką do przeprowadzenia oceny habitatowej jest ochrona gatunków i siedlisk cennych z punktu widzenia Unii Europejskiej, dla których utworzono obszar Natura 2000. Ocena ta, na mocy art. 46 pkt 1 wskazanej ustawy, jest przeprowadzana m.in. w odniesieniu do aktów planowania przestrzennego gminy. W trakcie opracowania studium uwarunkowań i kierunków zagospodarowania przestrzennego oraz m.p.z.p. należy ocenić na ile rozwiązania przyjęte w tych dokumentach mogą oddziaływać na równowagę przyrodniczą i trwałość procesów przyrodniczych ${ }^{30}$. Zarówno studia uwarun-

28 Dz.U. z 2013 r., poz. 1235.

29 Zob. A. Haładyj, op. cit., s. 164.

30 A. Fogel, Środowiskowe aspekty uprawnień społeczeństwa $w$ sporządzaniu studiów uwarunkowań i planów miejscowych, "Samorząd terytorialny" 2010, nr 5 (233), s. 47-48. 
kowań i kierunków zagospodarowania przestrzennego gminy, jak i m.p.z.p. prezentują przy tym bardzo wysoki poziom szczegółowości ustaleń dotyczących ochrony środowiska w zagospodarowaniu przestrzennym. Dlatego też analizy dotyczące SOOŚ podejmowane na tym etapie procesu inwestycyjnego stanowią bardzo ważny wektor ocen indywidualnych ${ }^{31}$. Jest to istotne w kontekście inwestycji realizowanych w gminie na obszarach objętych miejscowym planem zagospodarowania przestrzennego. Wskazania wynikające z SOOŚ, w odniesieniu do planu miejscowego, przekładają się $\mathrm{w}$ dużym stopniu na ocenę indywidualnych przedsięwzięć realizowanych na obszarze nim objętym. Warunkiem rzetelności strategicznej oceny oddziaływania na środowisko jest przy tym uwzględnienie wszystkich istniejących uwarunkowań przyrodniczych ${ }^{32}$, w tym także i tych, które związane są z ochroną różnorodności biologicznej w ramach sieci Natura 2000.

W toku oceny habitatowej analizie należy poddać przesłanki, których spełnienie, zgodnie z art. 33 i 34 u.o.p., pozwala na realizację projektowanego dokumentu, zastrzegając, że niespełnienie którejkolwiek z nich uniemożliwia jego przyjęcie i realizację. W świetle art. 33 u.o.p. „zabrania się, z zastrzeżeniem art. 34, podejmowania działań mogących, osobno lub w połączeniu z innymi działaniami, znacząco negatywnie oddziaływać na cele ochrony obszaru Natura 2000, w tym w szczególności: pogorszyć stan siedlisk przyrodniczych lub siedlisk gatunków roślin i zwierząt, dla których ochrony wyznaczono obszar Natura 2000; wpłynąć negatywnie na gatunki, dla których ochrony został wyznaczony obszar Natura 2000 lub pogorszyć integralność obszaru Natura 2000 lub jego powiązania z innymi obszarami". Powyższy zakaz nie dotyczy niemożności lokalizowania jakichkolwiek inwestycji na obszarze ochrony, ale tylko takich, które mogą na nie oddziaływać negatywnie, przy czym nega-

31 Zob. M. Pchałek, Procedura strategicznych ocen planów i programów a oceny oddziaływania na środowisko przedsięwzięć, w: Wybrane problemy prawa ochrony środowiska, red. B. Rakoczy, M. Pchałek, Warszawa 2010, s. 57.

32 Ibidem, s. 47-48. 
tywne oddziaływanie musi być znaczące ${ }^{33}$. O tym czy oddziaływanie jest znaczące decyduje szereg czynników, m.in.: rozmiar przedsięwzięcia, czas trwania, natężenie, częstotliwość, odwracalność, efekt kumulacji z oddziaływaniami innych przedsięwzięć $^{34}$. Granica pomiędzy oddziaływaniem znaczącym a nieistotnym jest trudna do uchwycenia, natomiast ocena musi być zawsze dokonywana in concreto ${ }^{35}$. Oznacza to, że przesłanka znaczącego negatywnego oddziaływania na obszar Natura 2000 powinna być badana w odniesieniu do konkretnego przypadku, którego konkretyzacji winien dokonać organ w toku oceny oddziaływania na środowisko. Istnienie rozwiązań alternatywnych musi rozważyć organ administracji „uwzględniając także koszty środowiskowe, czy społeczne realizacji alternatywnych rozwiązań $[\ldots]^{36}$.

Zakaz ustanowiony w art. 33 nie ma charakteru bezwzględnego. Właściwy miejscowo regionalny dyrektor ochrony środowiska, a na obszarach morskich - dyrektor właściwego urzędu morskiego może zezwolić na realizację planu lub działań, mogących znacząco negatywnie oddziaływać na siedlisko przyrodnicze oraz gatunki roślin i zwierząt, dla których ochrony został wyznaczony obszar Natura 2000, gdy spełnione są łącznie następujące przesłanki: 1) przemawiają za tym konieczne wymogi nadrzędnego interesu publicznego, w tym wymogi o charakterze społecznym lub gospodarczym; 2) brak jest rozwiązań alternatywnych, w stosunku do tych zawartych w planowanym lub projektowanym przedsięwzięciu; 3) zostanie zapewnione wykonanie kompensacji przyrodniczej niezbędnej do zapew-

33 Wyrok Naczelnego Sądu Administracyjnego z dnia 31 sierpnia 2010 r., II OSK 1323/09, opubl: Legalis. W świetle innego wyroku użycie kwantyfikatora „znacząco” wskazuje, że chodzi tu w istocie o negatywne oddziaływanie w dużym stopniu, przekraczającym przeciętną miarę. Nie każde negatywne oddziaływania na obszar Natura 2000 będzie oddziaływaniem „znaczącym". Zob. wyrok WSA w Rzeszowie z dnia 20 marca 2012 r., sygn. akt II SA/Rz 1111/11, opubl: Legalis.

34 J. Engel, Natura 2000 w ocenie oddziaływań przedsięwzięć na środowisko, Warszawa 2009, s. 22.

35 Por. A. Haładyj, op. cit., s. 168.

36 Wyrok Wojewódzkiego Sądu Administracyjnego siedziba w Warszawie z dnia 26 kwietnia 2007 r., IV SA/Wa 2319/06. 
nienia spójności i właściwego funkcjonowania sieci obszarów Natura 2000.

Wskazane wyżej przesłanki noszą cechy „stopniowalności”, co oznacza, że w pierwszej kolejności należy rozważyć istnienie rozwiązań alternatywnych, a dopiero po rzetelnym wykazaniu ich braku można przystąpić do „usprawiedliwiania” realizacji przedsięwzięcia ze względu na interes społeczny lub gospodarczy oraz do określania odpowiednich sposobów kompensacji przyrodniczej ${ }^{37}$. Organ administracji bierze przy tym pod uwagę istnienie faktycznych rozwiązań alternatywnych, czyli uwzględniających także koszty środowiskowe czy społeczne ich realizacji. Istnienie alternatywnego rozwiązania należy rozważać, mając na uwadze nie tylko szczególną potrzebę ochrony dóbr objętych specjalnymi formami ochrony przyrody (np. obszarów o znaczeniu międzynarodowym objętych siecią „Natura 2000"), ale także potrzeby racjonalnego równoważenia racji ochrony tych obszarów z innymi względami (m.in. społecznymi czy zachowania zasobów przyrody nieobjętych szczególnymi formami ochrony), nie pomijając zasady zrównoważonego rozwoju $^{38}$. Rozwiązania alternatywne w przypadku dokumentów planistycznych mają „niemal nieograniczoną liczbę możliwych wariantów [...], a wielość przeznaczeń terenu powoduje, że $\mathrm{w}$ istocie wariantowanie powinno dotyczyć nie tylko samego przeznaczenia terenu, lecz również interakcji oddziaływań, wynikających z ustalenia różnych przeznaczeń dla poszczególnych terenów"39.

Możliwość wykonania kompensacji zapewniającej spójność sieci obszarów Natura 2000 jest jednym z bezwzględnych warunków, które muszą być spełnione, aby zostało wydane zezwolenie na realizację planu, w stosunku do którego ocena habitatowa wykazała możliwość znaczącego negatywnego wpływu

${ }^{37}$ M. Bar, J. Jendrośka, Ocena oddziaływania przedsięwzięcia na środowisko a ocena oddziaływania na obszar Natura 2000, w: Wybrane problemy prawa ochrony środowiska, red. B. Rakoczy, M. Pchałek, Warszawa 2010, s. 34.

38 Wyrok Wojewódzkiego Sądu Administracyjnego siedziba w Olsztynie z dnia 13 grudnia 2011 r., II SA/Ol 878/1, opubl: Legalis.

39 A. Fogel, Strategiczna ocena oddziaływania na środowisko gminnych aktów planowania przestrzennego, „Samorząd Terytorialny” 2014, nr 9, s. 21. 
na cele ochrony obszaru Natura 2000 i jego integralność. Z tego powodu istotny jest czynnik czasowy, iż kompensacja winna być wykonana przed rozpoczęciem realizacji planu, który spowoduje znaczące negatywne oddziaływanie na cele ochrony obszaru Natura 2000 lub jego integralność. Działania kompensacyjne mają równoważyć straty $\mathrm{w}$ siedliskach przyrodniczych, populacjach gatunków roślin i zwierząt, co jednakowoż nie zwalnia z obowiązku poszukiwania rozwiązań alternatywnych.

W przypadku gdy znaczące negatywne oddziaływanie dotyczy siedlisk i gatunków priorytetowych, zezwolenie może zostać udzielone wyłącznie w celu: 1) ochrony zdrowia i życia ludzi; 2) zapewnienia bezpieczeństwa powszechnego; 3) uzyskania korzystnych następstw o pierwszorzędnym znaczeniu dla środowiska przyrodniczego; 4) wynikającym z koniecznych wymogów nadrzędnego interesu publicznego, po uzyskaniu opinii Komisji Europejskiej. W tym wypadku wystarczy, gdy spełniona zostanie przynajmniej jedna $\mathrm{z}$ powyższych przesłanek. Najbardziej pojemna wydaje się być ostatnia z nich. Nie chodzi tu o każdy rodzaj interesu publicznego, lecz musi on mieć charakter szczególny - nadrzędny. W praktyce przyjęto, że inwestycja musi realizować interes publiczny w sposób trwały, a nie opierać się wyłącznie na krótkotrwałych korzyściach. Z powodu braku definicji „koniecznych wymogów nadrzędnego interesu publicznego" można przyjąć, że obejmują one życie, zdrowie ludzi i bezpieczeństwo powszechne oraz korzystne skutki dla środowiska, np. redukcję zanieczyszczeń środowiska na innych obszarach, dostarczenie niezbędnej wody na tereny zagrożone jej brakiem itp. Niewątpliwie będzie to interes kwalifikowany w stosunku do interesów określonych w art. 34 ust 2 pkt 1-3 u.o.p. i musi się za nim kryć interes przewyższający wartość zasobów przyrodniczych, dla ochrony których utworzono dany obszar ${ }^{40}$. Warto zaznaczyć, że wymogu tego nie spełniają automatycznie inwestycje celu publicznego w rozu-

40 Szerzej na ten temat zob. S. Urban, Negatywne oddziatywanie planów i przedsięwzięć na sieć Natura 2000 a nadrzędny interes publiczny. Analiza pojęcia „powody o charakterze zasadniczym wynikajace z nadrzędnego interesu publicznego, w: Wspólnotowe prawo ochrony środowiska i jego implementacja 
mieniu przepisów ustawy o planowaniu i zagospodarowaniu przestrzennym.

\section{GOSPODAROWANIE OBSZARAMI NATURA 2000}

Obszary objęte siecią Natura 2000 są obszarami wykorzystywanymi gospodarczo. Sieć posiada duży zasięg przestrzenny i obejmuje obszary, na których są zlokalizowane podmioty reprezentujące różne branże: leśnictwo, rolnictwo, rybołówstwo, turystyka, rekreacja ${ }^{41}$. Zasady gospodarowania odnoszące się do ochrony najcenniejszych siedlisk oraz gatunków zwierząt i roślin na tych obszarach są inne niż w odniesieniu do rodzimych form ochrony przyrody. W przeciwieństwie do rezerwatów czy parków narodowych duża część obszarów Natura 2000 nie wymaga ostrych reżimów ochronnych, a podstawowym wymogiem jest niezmienianie dotychczasowych funkcji obszaru i niepogarszanie obecnego stanu siedlisk. Oznacza to, że położenie w obszarze Natura 2000 nie jest równoznaczne z zahamowaniem rozwoju gminy. Wprost przeciwnie - gospodarowanie obszarami Natura 2000, w sposób uwzględniający potrzeby ochrony przyrody, może stać się szansą na rozwój regionu. Takie postrzeganie gospodarowania na obszarach Natura 2000 ilustruje wyrok Naczelnego Sądu Administracyjnego z dnia 4 sierpnia 2009 r. $^{42}$, w którym sąd stwierdził, że - jeżeli działalność gospodarcza nie spowoduje negatywnych skutków dla chronionych gatunków zwierząt, dla których utworzono obszar Natura 2000 - to dopuszczalne jest rozpoczęcie takiej inwestycji. Również przepisy ustawy o ochronie przyrody pozwalają na prowadzenie na tych obszarach działalności gospodarczej, rolnej, leśnej, rybackiej

w Polsce trzy lata po akcesji, red. J. Jendrośka, M. Bar, Wrocław 2008, s. 149 i nast.

41 A. Bołtromiuk, Zrównoważony rozwój obszarów przyrodniczo cennych, t. 2: Gospodarcze i społeczne aspekty funkcjonowania sieci Natura $2000 \mathrm{w}$ parkach narodowych, Białystok 2011, s. 162.

42 II OSK $1239 / 08$. 
i łowieckiej pod warunkiem, że nie wpływa ona w istotny, negatywny sposób na gatunki zwierząt i roślin.

Jedną z barier dotyczących obszarów Natura 2000 jest obiegowa opinia, że ten rodzaj ochrony blokuje możliwości inwestycji budowlanych czy infrastrukturalnych. Tymczasem działalność gospodarcza na obszarach Natura 2000 jest dopuszczalna, pod warunkiem spełnienia określonych ustawowo przesłanek. Zgodnie bowiem z art. 36, ust. 1 u.o.p. obszarach Natura 2000, z zastrzeżeniem ust. 2, nie podlega ograniczeniu działalność związana z utrzymaniem urządzeń i obiektów służących bezpieczeństwu przeciwpowodziowemu oraz działalność gospodarcza, rolna, leśna, łowiecka i rybacka, a także amatorski połów ryb, jeżeli nie oddziałuje znacząco negatywnie na cele ochrony obszaru Natura 2000. W sytuacji nałożenia się reżimów publicznoprawnych, kiedy obszar Natura 2000 wchodzi w skład parków narodowych i rezerwatów przyrody, prowadzenie takiej działalności jest dozwolone wyłącznie w zakresie, w jakim nie narusza to zakazów obowiązujących na tych obszarach.

\section{PODSUMOWANIE}

Reasumując, obecność obszarów Natura 2000 nie powoduje wstrzymania rozwoju gospodarczego gmin, jedynie sposób przygotowania i realizacji inwestycji musi uwzględniać obecność tych obszarów tak, aby ingerencja w środowisko przyrodnicze była z jednej strony adekwatna do potrzeb rozwojowych gminy, z drugiej zaś eksponowała jej potencjał zasobowy. Koncepcja prawna obszarów Natura 2000 została pomyślana w taki sposób, aby łączyć potrzebę rozwoju gospodarczego gminy z poprawą jakości życia mieszkańców. Podnoszenie świadomości ekologicznej mieszkańców gminy i budowanie strategii rozwoju gminy poprzez łączenie gospodarki z ochroną bioróżnorodności w ramach sieci Natura 2000 to założenia, którymi powinien kierować się samorząd gminy. Narzędzia prawne planowania i zagospodarowania przestrzennego wraz z instytucjami towarzyszącymi procedurze planistycznej czy szerzej pro- 
cesowi inwestycyjnemu, jak strategiczne oceny oddziaływania na środowisko ${ }^{43}$, mają na celu sukcesywne podnoszenie kultury przyrodniczo-przestrzennej, uwzględniającej ochronę bioróżnorodności w ramach sieci Natura 2000.

\section{BIBLIOGRAFIA}

Bar M., J. Jendrośka J., Ocena oddziaływania przedsięwzięcia na środowisko a ocena oddziatywania na obszar Natura 2000, w: Wybrane problemy prawa ochrony środowiska, red. B. Rakoczy, M. Pchałek, Warszawa 2010.

Bołtromiuk A., Zrównoważony rozwój obszarów przyrodniczo cennych, t. 2, Gospodarcze i społeczne aspekty funkcjonowania sieci Natura 2000 w parkach narodowych, Białystok 2011.

Borkowski J., Kodeks Postępowania Administracyjnego - Komentarz, Warszawa 1996.

Ciechanowicz McLean J., Międzynarodowe prawo ochrony środowiska, Warszawa 1999.

Dudzik S., Konstytucyjna pozycja samorządu terytorialnego a perspektywy integracji europejskiej, w: Konstytucja Rzeczypospolitej Polskiej z 1997 roku a członkostwo Polski w Unii Europejskiej, red. C. Mik, Toruń 1999.

Ekspertyza przekrojowa dotycząca ekonomicznych uwarunkowań gospodarowania na Obszarach Natura 2000, Białystok 2012, http:// www.natura2000.efort.pl/pliki/ekspertyza_ekonomiczna1.pdf [online] [dostęp: 6 października 2015 r.].

Engel J., Natura 2000 w ocenie oddziatywań przedsięwzięć na środowisko, Warszawa 2009.

Fogel A, Środowiskowe aspekty uprawnień społeczeństwa $w$ sporządzaniu studiów uwarunkowań i planów miejscowych, „Samorząd terytorialny" 2010, nr 5.

43 Wypada w tym miejscu zaznaczyć, że zaliczenie strategicznej oceny oddziaływania na środowisko do kategorii instytucji prawa ochrony środowiska, zostało po raz pierwszy dokonane w pracy A. Haładyj pt. Udział społeczeństwa $w$ strategicznej ocenie oddziaływania na środowisko jako instytucja prawa ochrony środowiska, op. cit. 
Fogel A., Strategiczna ocena oddziatywania na środowisko gminnych aktów planowania przestrzennego, „Samorząd Terytorialny” 2014, nr 9.

Gajda A., Organy regionalne i lokalne a prawo wspólnotowe, w: Efektywność prawa wspólnotowego w Polsce. Wybrane problemy, red. J. Barcz, „Studia z dziedziny prawa Unii Europejskiej” 2005, nr 3.

Haładyj A., Udział społeczeństwa $w$ strategicznej ocenie oddziaływania na środowisko jako instytucja prawa ochrony środowiska, Lublin 2015.

Jać M., P. Jać P., Planowanie przestrzenne - o potrzebie i kierunkach zmian, w: Kierunki reformy prawa planowania $i$ zagospodarowania przestrzennego, red. I. Zachariasz, Warszawa 2012.

Kaźmierska-Patrzyczna A., Istota prawna obszarów Natura 2000 - uwagi ogólne, w: Problemy wdrażania systemu Natura 2000 w Polsce, red. A. Kaźmierska-Patrzyczna, M. A. Król, Szczecin-Łódź-Poznań 2013.

Mik C., Polskie organy państwowe wobec perspektywy przystapienia $R P$ do Unii Europejskiej, w: Polska w Unii Europejskiej. Perspektywy, warunki, szanse i zagrożenia, red. C. Mik, TNOiK Toruń 1997.

Nowacki K., Zadania, kompetencje i formy działania organów administracji publicznej $w$ dziedzinie ochrony środowiska $i$ zagospodarowania przestrzennego (wybrane problemy), w: Ustrój administracji publicznej, red. E. J. Nowacka, Warszawa 2000.

Nowak-Far A., Stosowanie acquis communautaire przez administracje publiczne państw członkowskich Unii Europejskiej - zagadnienia prawne i organizacyjne, „Służba Cywilna” 2002, nr 4.

Paczuski R., Prawo ochrony środowiska Unii Europejskiej w zarysie, Toruń 1999.

Pchałek M., Procedura strategicznych ocen planów i programów a oceny oddziatywania na środowisko przedsięwzięć, w: Wybrane problemy prawa ochrony środowiska, red. B. Rakoczy, M. Pchałek, Warszawa 2010.

Rabska T., Administracja publiczna $w$ świetle integracji z Uniq Europejska, ,Samorząd Terytorialny” 2003, nr 3.

Sage E. D, Stosowanie prawa i polityk Unii Europejskiej przez wtadze lokalne, Warszawa 2000.

Stelmasiak J., Miejscowy plan zagospodarowania przestrzennego jako prawny środek ochrony środowiska, Lublin 1994, tenże, Interes indywidualny a interes publiczny $w$ ochronie środowiska $w$ obszarze specjalnym o charakterze ekologicznym, Rzeszów 2013. 
Trzcińska D., Natura 2000 a ograniczenie korzystania z nieruchomości, w: Wybrane problemy prawa ochrony środowiska, red. B. Rakoczy, M. Pchałek, Warszawa 2010.

Urban S., Negatywne oddziaływanie planów i przedsięwzięć na sieć Natura 2000 a nadrzędny interes publiczny. Analiza pojęcia „powody o charakterze zasadniczym wynikajace z nadrzędnego interesu publicznego, w: Wspólnotowe prawo ochrony środowiska $i$ jego implementacja $w$ Polsce trzy lata po akcesji, red. J. Jendrośka, M. Bar, Wrocław 2008.

Waligórski M. A., Koordynacja $w$ administracji publicznej, w: Ewolucja prawnych form administracji publicznej. Księga jubileuszowa z okazji 60 rocznicy urodzin profesora Ernesta Knosali, red. L. Zacharko, AS. Matan, G. Łaszczyca, Warszawa 2008.

Zieliński M., Wptyw członkostwa Polski w Unii Europejskiej na samorzq̨d terytorialny, w: Przystapienie Polski do Unii Europejskiej. Traktat Akcesyjny i jego skutki, red. S. Biernat, S. Dudzik, M. Niedźwiedź, Kraków 2003.

Kontakt e-mail:

martawozniak1@o2.pl 